\title{
ANALISIS KADAR FLOURIDA PADA BEBERAPA AIR KEMASAN BERMERK YANG BEREDAR DI KECAMATAN RAPPOCINI KOTA MAKASSAR
}

\author{
Nuradi $^{1}$, Jangga $^{2}$ \\ ${ }^{1}$ Jurusan Analis Kesehatan Poltekkes Kemenkes Makassar \\ ${ }^{2}$ Stikes Mega Rezki Makassar
}

Korespodensi : nuradi.poltekkes.mks@gmail.com

\begin{abstract}
ABSTRAK
Air minum dapat pula mengandung flourida alami atau flourida yang memang ditambahkan sebagai bahan pelindung untuk gigi oleh perusahaan air minum. Namun, kehadirannya bukan tanpa kontroversi, karena di beberapa daerah, kadar flourida alami dalam air sudah diatas ambang batas yang dianggap aman oleh Organisasi Kesehatan Dunia (WHO) yang menunjukkan tingkat yang aman dari flourida adalah 1,5 miligram per liter. Tujuan penelitian dalam penelitian ini adalah untuk menentukan kadar flourida pada air kemasan bermerek yang beredar di Kecamatan Rappocini Makassar. Jenis penelitian ini adalah merupakan penelitian deskriptif yang dilakukan secara observasi laboratorik, yaitu dengan melakukan pemeriksaan kadar flourida pada air kemasan. Hasil penelitian menunjukkan bahwa dari ke 5 sampel air minum kemasan beberapa merek di Kecamatan Rappocini yaitu semuanya masih dalam nilai ambang batas normal. Oleh karena itu disarankan bahwa pada dosis yang besar, fluoride bisa membahayakan kesehatan, namun pada dosis yang kecil fluorida justru bermanfaat, oleh karena itu sebaiknya komsumsi air kemasan yang kadar flouridanya kurang dari $1 \mathrm{mg} / \mathrm{l}$ untuk bisa mencegah timbulnya karang gigi dan gigi yang berlubang.bor.
\end{abstract}

Kata kunci : Flourida, Air Kemasan Bermerek

\section{PENDAHULUAN}

Air memegang peranan penting bagi kehidupan manusia, hewan, tumbuhan dan jasad-jasad lain. Air yang kita perlukan adalah air yang memenuhi persyaratan kesehatan baik persyaratan fisik, kimia, bakteriologis dan radioaktif. Air yang tidak tercemar didefinisikan sebagai air yang tidak mengandung bahan asing tertentu dalam jumlah melebihi batas yang ditetapkan sehingga air tersebut dapat dipergunakan secara normal (Sutrisno,T, 2010).

Dalam tubuh manusia sebagian besar terdiri dari air. Tubuh orang dewasa sekitar 55-56 \% berat badan terdiri dari air, untuk anak- anak sekitar $65 \%$ dan untuk bayi sekitar $80 \%$. Kebutuhan manusia akan air sangat kompleks antara lain untuk minum, mandi, masak, mencuci dan sebagainya. Menurut WHO di negara-negara maju tiap orang memerlukan air antara 60-120 liter per hari, sedangkan di negara-negara berkembang termasuk Indonesia tiap orang memerlukan 20-60 liter per hari (Notoatmodjo, 2003).

Setelah 22 tahun melakukan penelitian, Harvard University menemukan betapa bahayanya Air Minum Dalam Kemasan (AMDK) yang mengandung flouride. Temuan terkini dari Harvard University itu menyatakan bahwa air minum dalam kemasan dengan Fluorida juga dapat mengurangi IQ anakanak. (Slade, dkk. 2013).

Air minum dapat pula mengandung flourida alami atau flourida yang memang ditambahkan sebagai bahan 
pelindung untuk gigi oleh perusahaan air minum. Namun, kehadirannya bukan tanpa kontroversi, karena di beberapa daerah, kadar flourida alami dalam air sudah diatas ambang batas yang dianggap aman oleh Organisasi Kesehatan Dunia (WHO) yang menunjukkan tingkat yang aman dari flourida adalah 1,5 miligram per liter. (Slade, dkk. 2013)

Pada air kemasan kadar flourida yang masih dianggap sehat yaitu berdasarkan WHO pada tahun 1984 dan 1993 menetapkan standar kandungan flourida dalam air kemasan tidak boleh melebihi $1,5 \mathrm{mg} /$ liter. Melebihi batas standar ini dapat menyebabkan risiko fluorosis gigi, pada kadar yang lebih besar lagi dapat menyebabkan fluorosis tulang. (SNI, 2005).

Di Indonesia sendiri, melalui Peraturan Menteri Kesehatan Republik Indonesia No. 492/Menkes/Per/IV/2010 tentang persyaratan kualitas air Minum, kandungan flourida dalam air minum tidak boleh melebihi $1,5 \mathrm{mg} / \mathrm{L}$, Batasan yang lebih ketat justru ditetapkan oleh SNI 013553-2006 Tentang Air Minum dalam Kemasan, disebutkan bahwa kandungan flourida dalam air mineral tidak boleh melebihi $1 \mathrm{mg} / \mathrm{L}$. (SNI, 2005)

Masuknya fluorida ke dalam tubuh dapat terjadi secara sistemik dan lokal. Secara sistemik antara lain melalui fluoridasi air minum dan tablet fluorida, garam dapur dan susu yang mengandung fluorida, sedangkan secara lokal melalui topikal aplikasi fluor dan produk kesehatan pasta gigi, obat kumur fluor dan lain-lain.

Fluorida dalam air minum memiliki efek pada gigi dan tulang. Ion fluorida akan menggantikan ion hidroksida pada hidroksiapatit $\mathrm{Ca} 5(\mathrm{PO} 4) 3 \mathrm{OH}$ suatu mineral penting yang menyusun enamel gigi dan tulang. Keberadaan ion fluorida dalam enamel gigi menjadikannya lebih kuat tapi rapuh. Menurut batasan yang dikeluarkan oleh World Health
Organization (WHO) tahun 1985 bahwa ion fluorida memiliki efek menguntungkan apabila kadarnya sekitar $0,7 \mathrm{mg} / \mathrm{L}$, tapi sangat berbahaya apabila lebih dari 1,5 mg/L. (Slade, dkk. 2013).

Pada rentangan kadar fluorida 1-1,5 $\mathrm{mg} / \mathrm{L}$ akan cukup untuk memperkuat enamel gigi. Pada rentangan 1,5-4 mg/L dapat menyebabkan dental fluorisis, dan apabila terpapar flourida dalam rentang kadar 4-10 mg/mL dalam jangka waktu yang lama selain sebabkan dental fluorisis juga dapat terjadi skeletal atau tulang fluorisis. Kondisi skeletal fluorisis akan menyebabkan tulang penyangga tubuh menjadi rapuh. Efek dari fluorida dalam air minum terhadap pencegahan karies gigi cukup signifikan pada kadar yang diijinkan. (Slade, dkk. 2013).

Masuknya fluorida ke dalam tubuh melalui hal tersebut secara berlebihan dalam jangka waktu pendek maupun panjang dapat menimbulkkan terjadinya toksikasi secara akut dan kronik. Toksikasi kronik lebih sering terjadi daripada toksikasi akut. (Anonim, 2001)

Menurut Peraturan Pemerintah Republik Indonesia No. 82 Tahun 2001 tentang pengelolaan kualitas air dan pengendalian pencemaran air dinyatakan bahwa kadar fluorida sebagai parameter kimia inorganik dalam kelas air kelas I yaitu air yang diperuntukannya dapat digunakan untuk air baku air minum dan atau peruntukan lain yang mempersyaratkan mutu air yang sama dengan kegunaan tersebut yang dipertegas kembali dalam Keputusan Menteri Kesehatan Repubik Indonesia No. 907/2002 tentang syarat-syarat dan pengawasan kualitas air minum dinyatakan bahwa fluorida merupakan bahan kimia inorganik yang memiliki pengaruh langsung pada kesehatan maksimum yang diperbolehkan atau yang dipersyaratkan adalah 1,5 mg/L. (Anonim, 2002).

Berdasarkan uraian diatas maka peneliti berkeinginan melakukan 
penelitian untuk menentukan kadar flourida pada beberapa merek air kemasan yang beredar di Kota Makassar.

\section{METODE}

Jenis penelitian adalah observasi laboratorik bersifat deskriptif analitik dengan teknik analisa kuantitatif untuk menentukan kadar flourida pada air kemasan bermerek.

Penelitian ini dilaksanakan di Balai Besar Laboratorium Kesehatan Makassar pada bulan Juni 2017. Sampel yang digunakan yaitu air kemasan bermerek yang beredar di Kota Makassar sebanyak 5 sampel, secara random sampling.

Alat penelitian yang digunakan adalah: Spektrofotometer sinar tampak yang mempunyai kisaran panjang gelombang $190 \mathrm{~nm}$ - $900 \mathrm{~nm}$ dan lebar celah $0,2 \mathrm{~nm}-2 \mathrm{~nm}$ serta telah dikalibrasi. Alat yang digunakan yaitu :Pipet $5 \mathrm{ml}, 10$ $\mathrm{ml}$ dan $50 \mathrm{ml}$ terkalibrasi, labu ukur $50 \mathrm{ml}$, $100 \mathrm{ml}$ dan $1000 \mathrm{ml}$, terkalibrasi, buret 25 $\mathrm{ml}$, terkalibrasi,labu erlenmeyer asah 100 $\mathrm{ml}$, neraca analitik dengan ketelitian 0,1 mg.

\section{Prosedur Kerja}

\section{Prinsip}

Metode spektrofotometri SPADNS berdasarkan reaksi fluorida dan penyerapan warna zirkonium. Fluorida bereaksi dengan penyerapan warna zirkonium membentuk

anion kompleks yang tidak berwarna $\mathrm{ZrF6}^{2}$.

\section{Pereaksi}

a. Larutan baku flourida

Dilarutkan 221,0 mg natrium flourida anhidrat $\mathrm{NaF}$ dengan air suling di dalam labu ukur $1000 \mathrm{ml}$ dan encerkan dengan tepat tanda tera.

b. Dilarutan SPADNS (sodium 2parasulfofenylazo 20-1,8dihidroxy-3,6-naftalene disulfanat)

c. Larutan asam zirkonil

Ditimbang $133 \mathrm{mg}$ zirkonil klorida oktahidrat, $\mathrm{ZrOCl}_{2} . \mathrm{H} 2 \mathrm{O}$ dan dilarutkan dalam $25 \mathrm{ml}$ air suling. Tambahkan $350 \mathrm{ml} \mathrm{HCl}$ pekat dan diencerkan dengan air suling sampai $500 \mathrm{ml}$

d. Larutan pembanding

Ditambahkan $10 \quad \mathrm{ml}$ larutan SPADNS ke dalam $100 \mathrm{ml}$ air suling.

e. Larutan natrium arsenit $(\mathrm{NaAs}, \mathrm{O} 2)$ Dilarutkan 5,0 g NaAsO2 dengan air suling dan diencerkan hingga 1000 $\mathrm{ml}$.

\section{Persiapan Sampel}

a. Dipipet $50 \mathrm{ml}$ sampel uji secara duplo dan dimasukkan ke dalam labu Erlenmeyer $100 \mathrm{ml}$.

b. Apabila contoh uji keruh, disaring contoh uji dengan saringan membran berpori $0,45 \mathrm{~mm}$

c. Apabila contoh uji mengandung klorin ditambahkan satu tetes larutan natrium arsenit, setiap contoh uji mengandung $0,1 \mathrm{mg} / \mathrm{l}$ klorin

d. Contoh siap diuji.

\section{Cara kerja}

a. Pembuatan kurva kalibrasi

Disiapkan standar fluorida dengan kepekatan $0-1,40 \mathrm{mg} / \mathrm{l}$ fluorida. Pipet 1.0, 2.0, 3.0, 4.0, 5.0 dan $6 \mathrm{ml}$ larutan standar dimasukkan ke dalam labu $50 \mathrm{ml}$, tepatkan sampai tanda tera dengan air suling dan dikocok sampai serba sama.

b. Dipipet $50 \mathrm{ml}$ contoh ke dalam Erlenmyer asah $100 \mathrm{ml}$

c. Ditambahkan $5 \mathrm{ml}$ larutan SPADNS dan $5 \mathrm{ml}$ asam zirkonil klorida atau $10 \mathrm{ml}$ larutan campuran SPADNS dan asam zirkonil klorida. dikocok sampai serba sama;

d. Dibaca absorben larutan standar dan contoh pada alat spektrofotometer pada panjang gelombang $570 \mathrm{~nm}$.

\section{Perhitungan}

Dihitung kadar fluorida di dalam contoh dengan menggunakan kurva kalibrasi atau persamaan garis regresi linier. 


\section{Pengolahan Data}

Pengolahan data dilakukan secara deskriptif disajikan dalam bentuk tabel disertai narasi dan dilaporkan dalam persentase dengan menggunakan rumus :

$$
\% \text { Flourida }={ }_{\mathrm{T}}^{\mathrm{P}} \times 100 \%
$$

Keterangan :

$\mathrm{P}=$ Jumlah sampel yang abnormal

$\mathrm{T}=$ jumlah keseluruhan sampel

\section{HASIL}

Berdasarkan hasil penelitian yang dilakukan di Balai Besar Laboratorium Kesehatan Makassar pada Juni 2017 sebanyak 5 sampel. Berdasarkan hasil penelitian pada tabel 1 menunjukkan bahwa kadar flourida pada kode sampel 1 yaitu sebanyak 0,87 , kode sampel 2 sebanyak 0,69, kode sampel 3 sebanyak 0,30 , kode sampel 4 sebanyak 0,71 , dan kode sampel 5 sebanyak 0,07.

\section{PEMBAHASAN}

Kandungan fluorida dalam air yang kita konsumsi sehari-hari bervariasi, air tanah yang melewati pegunungan biasanya akan termineralisasi secara alami dan akan mengandung flourida. Tinggi rendahnya kandungan flourida tergantung dari batuan dan mineral yang dilewatinya. Setelah diminum atau dimakan, hampir seluruh flourida akan diserap oleh pencernaan kita, masuk aliran darah, dan disimpan di tulang atau gigi.

Dosis sejumlah $0,7 \mathrm{mg} /$ liter cukup untuk memberikan efek yang baik bagi tulang dan gigi. Namun, dosis yang berlebihan justru dapat menyebabkan kerusakan tulang dan gigi. Fluorosis gigi kelainan enamel yang diebabkan oleh konsumsi flourida yang berlebihan terjadi apabila kandungan flourida dalam air berkisar antara 1,5-2 mg/liter, tergantung seberapa banyak seseorang meminum air tersebut. Fluorosis gigi sering terjadi pada usia anak 22-26 bulan di mana terjadi pertumbuhan dan mineralisasi gigi. Selain itu, konsumsi berlebihan juga dapat menyebabkan keracunan flourida akut yang bisa terjadi apabila mengkonsumsi flourida sebanyak lebih dari 1 gr setiap $\mathrm{kg}$ berat badan.

Analisis flourida dilakukan dengan menggunakan metode spektrofotometri SPADNS yang berdasarkan pada reaksi flourida dan penyerapan warna zirconium yang membentuk anion kompleks yang tidak berwarna. Semakin tinggi konsentrasi flourida dalam larutan, maka terjadi pengurangan serapan kompleks pereaksi SPADNS yang menyebabkan nilai serapannya juga menurun. Pereaksi SPADNS yang semula berwarna merah menjadi pudar dan cenderung menjadi jingga seiring dengan peningkatan jumlah ion flourida yang bereaksi, dengan demikian nilai serapannya pada pengamatan di daerah cahaya tampak juga menurun.

Berdasarkan hasil penelitian menunjukkan bahwa kadar flourida pada kode sampel 1 yaitu sebanyak 0,87 , kode sampel 2 sebanyak 0,69, kode sampel 3 sebanyak 0,30 , kode sampel 4 sebanyak 0,71, dan kode sampel 5 sebanyak 0,07. SNI 01-3553-2006 menetapkan kandungan flourida dalam air kemasan $<0,5 \mathrm{mg} / \mathrm{L}$. Air kemasan yang memenuhi standar di atas biasanya memiliki label dan nomor SNI tersebut.

Di Indonesia sendiri, melalui Peraturan Menteri Kesehatan Republik Indonesia No. 492/Menkes/Per/IV/2010 tentang persyaratan kualitas air Minum, kandungan flourida dalam air minum tidak boleh melebihi $1,5 \mathrm{mg} / \mathrm{L}$, Batasan yang lebih ketat justru ditetapkan oleh SNI 013553-2006 Tentang Air Minum dalam Kemasan, disebutkan bahwa kandungan flourida dalam air mineral tidak boleh melebihi $1 \mathrm{mg} / \mathrm{L}$.

Hasil dalam penelitian ini menunjukkan bahwa dari ke 5 sampel air minum kemasan beberapa merek di Kecamatan Rappocini yaitu semuanya masih dalam nilai ambang batas normal. 
Pada dosis yang besar, fluorida bisa membahayakan kesehatan, namun pada dosis yang kecil flourida justru bermanfaat bagi kita. Flourida ditambahkan pada air kemasan atau pasta gigi dikarenakan zat ini bisa mencegah timbulnya karang gigi dan gigi yang berlubang. Flourida juga bermanfaat bagi kesehatan tulang. Penambahan flourida merupakan salah satu cara paling efektif dan murah untuk mencegah karies gigi.

\section{KESIMPULAN}

Berdasarkan hasil penelitian yang dilakukan maka ditarik suatu kesimpulan bahwa dari ke 5 sampel air minum kemasan beberapa merek di Kecamatan Rappocini yaitu semuanya masih dalam nilai ambang batas normal.

\section{SARAN}

Adapun saran dalam penelitian ini yaitu bahwa pada dosis yang besar, fluorida bisa membahayakan kesehatan, namun pada dosis yang kecil fluorida justru bermanfaat, oleh karena itu sebaiknya komsumsi air kemasan yang kadar flouridanya kurang dari $1 \mathrm{mg} / \mathrm{l}$ untuk bisa mencegah timbulnya karang gigi dan gigi yang berlubang.

\section{DAFTAR PUSTAKA}

Anonim. 2001. Peraturan Pemerintah Republik Indonesia No. 82 Tahun 2001 tentang pengelolaan kualitas air dan pengendalian pencemaran air. Jakarta: Departemen Kesehatan.

Anonim. 2002. Keputusan Menteri Kesehatan Republic Indonesia Nomor 907/MENKES/SK/VII/2002 tentang Syarat-Syarat dan Pengawasan Kualitas Air Minum. Jakarta : Kementerian Kesehatan Republik Indonesia.

Arifin, B., Deswati, \& Loekman U. (2012). Analisis Kandungan Logam $\mathrm{Cd}, \mathrm{Cu}, \mathrm{Cr}$, dan $\mathrm{Pb}$ dalam Air Laut di Sekitar Perairan Bungus Teluk
Kabung Kota Padang.Jurnal Teknik Lingkungan UNAND 9 (2), 139-

Day, R.A. dan Underwood, A.L. 2003. Analisis kimia kuantitatif (Edisi Keenam).Jakarta: Erlangga

Gandasoebrata R, 2008 ,Penuntun Laboratorium Klinik. Dian rakyat. Jakarta.

Priyanto, 2009. Farmakoterapi \& Terminologi Medis.Leskonfi, Jakarta Hal: 156-163.

Sarwono W. 1995.Ilmu Penyakit Dalam.Bagian Ilmu Penyakit Dalam FK,UI. RSUP Nasional Cipto Mangunkusumo,Hal: 203-211.

Slade, G.D., Sanders, A.E., Do, L.,Roberts-Thomson, K., Spencer, A.J.2013.Effects of Fluoridated Drinking Water on Dental Caries in Australian Adults. Journal of Dental Research. Vol. XX hal. 1-7.

SNI 06-6989.29-2005 Air dan air limbah Bagian 29 : Cara uji fluorida $\left(\mathrm{F}^{-}\right)$ secara spektrofotometri dengan SPADNS.

Standard Methods For The Examination of Water and Wastewater. American Public Health Association; American Water Works Association: Water Environment Federation.20th Ed. Washington DC, APHA, 1998.

Sugiyono. 2003. Statistika Untuk Penelitian. CV Alfabeta. Bandung Svehla, G. 1985. Vogel Buku analisis anorganik kualitatif makro dan semimikro (edisi kelima). Jakarta: PT. Kalman Media Pusaka. 
Tabel 1.Hasil Penelitian Kadar Flourida Pada Beberapa Merek Air Minum Kemasan Yang Beredar di Kecamatan Rappocini

\begin{tabular}{ccc}
\hline No & Kode Sampel & Hasil (mg/l) \\
\hline 1 & 1 & 0,87 \\
\hline 2 & 2 & 0,69 \\
\hline 3 & 3 & 0,30 \\
\hline 4 & 4 & 0,71 \\
\hline 5 & 5 & 0,07
\end{tabular}

